\title{
Non-Radiological Air Quality Modeling for the High-Level Waste Salt Disposition Environmental Impact Statement
}

by

RECORDS ADMINISTRATION

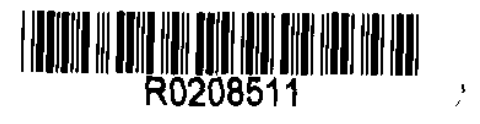

C. H. Hunter

Westinghouse Savannah River Company

Savannah River Site

Aiken, South Carolina 29808

This paper was prepared in connection with work done under the above contract number with the U. S.

Department of Energy. By acceptance of this paper, the publisher and/or recipient acknowledges the U. S.

Government's right to retain a nonexclusive, royalty-free license in and to any copyright covering this paper, along with the right to reproduce and to authorize others to reproduce all or part of the copyrighted paper. 


\section{DISCLAIMER}

This report was prepared as an account of work sponsored by an agency of the United States Government. Neither the United States Government nor any agency thereof, nor any of their employees, makes any warranty, express or implied, or assumes any legal liability or responsibility for the accuracy, completeness, or usefulness of any information, apparatus, product or process disclosed, or represents that its use would not infringe privately owned rights. Reference herein to any specific commercial product, process or service by trade name, trademark, manufacturer, or otherwise does not necessarily constitute or imply its endorsement, recommendation, or favoring by the United States Government or any agency thereof. The views and opinions of authors expressed herein do not necessarily state or reflect those of the United States Government or any agency
thereof.

This report has been reproduced directly from the best available copy.

Available for sale to the public, in paper, from: U.S. Department of Commerce, National Technical Information Service, 5285 Port Royal Road, Springfield, VA 22161, phone: (800) 553-6847,

fax: (703) 605-6900

email: orders@ntis.fedworld.gov

online ordering: http://www.ntis.gov/ordering.htm

Available electronically at http://www.doe.gov/bridge

Available for a processing fee to U.S. Department of Energy and its contractors, in paper, from: U.S. Department of Energy, Office of Scientific and Technical Information, P.O. Box 62, Oak Ridge, IN 37831-0062, phone: (865)576-8401,

fax: (865) 576.5728

email : reportscadonis.osti.gov 


\section{Non-Radiological Air Quality Modeling for the High-Level Waste Salt Disposition Environmental Impact Statement (U)}

C. H. Hunter 


\section{Table of Contents}

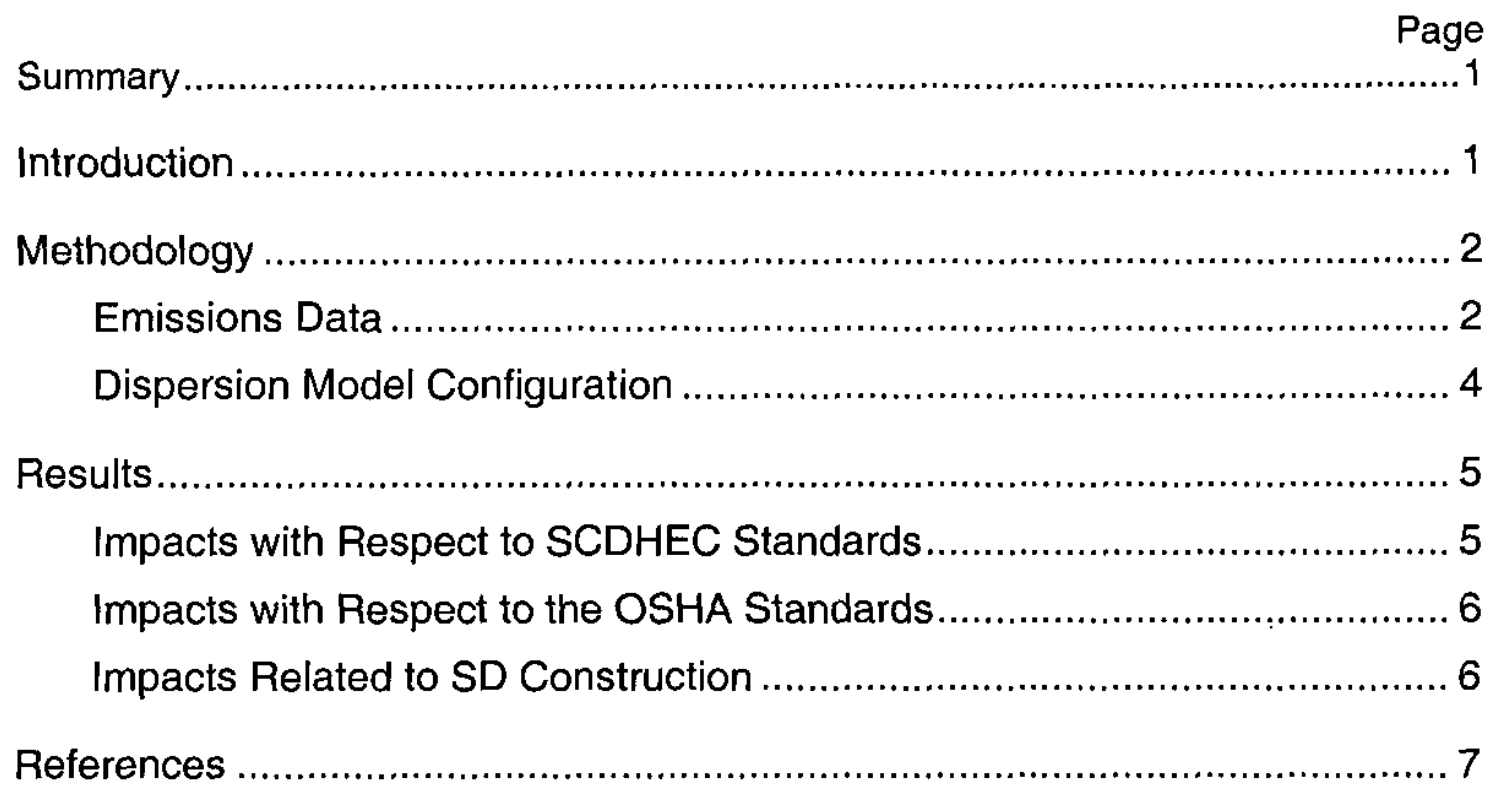




\section{List of Tables}

1 Source Data for Proposed SD Facilities (All Alternatives) ...................... 8

2 Summary of Non-radiological Air Emissions for

HLW SD Sources - Operations

3 Non-radiological Air Emissions from Construction (All Alternatives)........13

4 Estimated Maximum Ambient Concentration $\left(\mu \mathrm{g} / \mathrm{m}^{3}\right)$ at the SRS Boundary for Standard 2 Air Pollutants- SD Operations 14

5 Estimated Maximum 24-Hour Concentrations $\left(\mu \mathrm{g} / \mathrm{m}^{3}\right)$ at the SRS Boundary for Standard 8 Air Pollutants - SD Operations.

6 Estimated Cumulative Ground-Level Concentrations $\left(\mu \mathrm{g} / \mathrm{m}^{3}\right)$ of Non-radiological Air Pollutants at the SRS Boundary - SD Operations (Preferred Alternative) plus Emissions from Potential Future Activities

7 Estimated Maximum Concentration in $\left(\mathrm{mg} / \mathrm{m}^{3}\right)$ of Air Pollutants Regulated by OSHA - SD Operations.

8 Estimated Maximum Concentration $\left(\mu \mathrm{g} / \mathrm{m}^{3}\right)$ of Regulated Air Pollutants at the SRS Boundary - SD Construction 19

9 Estimated Maximum Concentration $\left(\mathrm{mg} / \mathrm{m}^{3}\right)$ of Air Pollutants Regulated by OSHA - SD Construction 


\section{Summary}

This report summarizes the results of dispersion modeling for emissions of nonradiological air pollutants associated with the construction and operation of four alternatives for high-level waste salt disposition at SRS. These data are intended for use by DOE-Savannah River in the preparation of the salt disposition supplemental environmental impact statement (DOE/EIS-0082-S2).

Estimated maximum ground-level concentrations of applicable regulated air pollutants at the site boundary and at the distance to a hypothetical, co-located onsite worker (640 meters) are summarized in Tables 4-7 (facility operations) and 8-9 (facility construction). In all cases, model estimated ambient concentrations are less than regulatory standards.

\section{Introduction}

The salt disposition (SD) supplemental environmental impact statement (SEIS) defines four alternatives for processing highly radioactive salt solutions stored in the $\mathrm{F}$ and $\mathrm{H}$ Area Tank Farms: (1) small tank precipitation (STP) with sodium tetraphenylborate, (2) caustic-side solvent extraction (CSSX), (3) non-elutable Ion Exchange (IE) with crystalline silicotitanate, and (4) direct disposal in grout (DG) (DOE, 1998). Nonradiological air emissions associated with the construction and operation of facilities supporting each of these alternatives will include regulated 'criteria' and toxic air pollutants. The 'criteria' pollutants consist of sulfur dioxide $\left(\mathrm{SO}_{2}\right)$, nitrogen dioxide $\left(\mathrm{NO}_{2}\right.$ ), carbon monoxide (CO), total suspended particulates (TSP), particulate matter less than 10 micron diameter (PM-10), ozone, lead, and gaseous fluorides. Ambient concentration standards for these pollutants are defined by South Carolina Department of Health and Environmental Control (SCDHEC) Air Pollution Regulation 61-62.5, Standard 2. Ambient standards for toxic air pollutants are defined by SCDHEC Air Pollution Regulation 61-62.5, Standard 8. These standards are applicable to the general public and, for SRS emissions, are evaluated at the site boundary.

In addition, the Occupational Safety and Health Administration (OSHA) has established ambient concentration standards for the workplace. These standards are defined in the Code of Federal Regulations, Chapter 29, Part 1910.1000 and are evaluated with respect to a hypothetical uninvolved (co-located) worker. For the purposes of the EIS, the colocated worker is generically defined to be 640 meters from the proposed facility.

To support preparation of this EIS, the SRTC Atmospheric Technologies Group was requested to model $\mathrm{SD}$-related air emissions and evaluate the impacts of these emissions with respect to ambient standards. New facilities required to implement the STP, CSSX, and IE alternatives were assumed to be located at SD proposed Site B, about 950 feet southeast of DWPF (Gladden, 1999); new facilities required for the DG alternative were assumed to be located adjacent to the existing Saltstone facility in Z-area (Pike, 2000). 


\section{Methodology}

\section{Emissions Data}

Estimates of non-radiological air emissions for each of the four SD alternatives were developed by High Level Waste Engineering (Pike, 2000). For each alternative, the primary sources of air pollution during SD operations will be a process building exhaust stack, a cold chemical feeds building exhaust stack, and two emergency diesel generators, which will be used for backup power. In addition, emissions associated with the STP, CSSX, and IE alternatives will include existing sources in Z-area (Saltstone processing facilities and an emergency diesel generator). The process canyon, cold feeds facility, and diesel generators constructed for the DG alternative are assumed to replace the existing Zarea sources.

Source configuration and emissions data by alternative are summarized in Tables 1 and 2, respectively. Data for the Z-area sources were taken from the current SRS Air Emissions Inventory (AEI) database (AEI source identifiers ZDE12, ZDP71, ZDP72, ZDP88, ZDP91, ZDT1, ZDT2) and Pike (2000). The two backup diesel generators were assumed to be identical to those currently operating at the Defense Waste Processing Facility (DWPF) (AEI source identifiers STE2, STE3). All emissions data, whether for new facilities or from the SRS Air Emissions Inventory, are considered maximum potential emissions. Emissions from process facilities are expected to be continuous. Maximum hourly emissions rates were used for all dispersion calculations with concentration averaging times 24 hours or less; otherwise, an average emission rate based on total annual emissions was used. Backup diesel generators are projected to operate 250 hours per year, primarily for testing. For modeling purposes, each unit was conservatively assumed to operate concurrently one hour per day (5 PM) at the hourly maximum potential emission rate.

Estimated emissions of regulated air pollutants associated with SD construction are summarized in Table 3. These emissions were calculated from standard EPA methods using data supplied by Sessions (1999). Construction-related sources of air pollution include criteria pollutants in the exhaust of diesel equipment, and particulate matter from excavation and transfers of soils, stirring of surface dust by the movement of heavy equipment, and the operation of a concrete batch plant. Emissions were determined for each of two distinct phases of construction, site preparation and facility construction. Site preparation is expected to require 120 ten-hour workdays; facility construction is expected to require 200 ten-hour workdays until completion. Construction requirements for each of the four alternatives were assumed to be identical.

Pollutant-specific emission rates for diesel exhaust were calculated from emission factors by equipment type (grams of pollutant per horsepower-hour), as defined in EPA (1991), and equipment inventories provided by Sessions (1999). The hourly emission rates shown in Table 3 for the four primary criteria pollutants are a sum of emissions over all equipment categories adjusted by an average use factor of 0.5 (the fraction of the vehicle fleet that is in use at any given time on the average). 
Three sources of fugitive particulates (dust) were considered: the transfer of excavated soil to haul trucks for removal, grading activities, and the stirring of dust from cleared, unpaved surfaces by the movement of heavy equipment.

1. Fugitive emissions from batch transfer of soils to or from haul trucks (in kilograms of dust per megagram of soil transferred) are given by EPA (1995) as:

$$
\mathrm{E}=\mathrm{k}(0.0016)(\mathrm{U} / 2.2)^{1.3} /(\mathrm{M} / 2)^{1.4}
$$

where

$\mathrm{k}$ is a multiplier for particle size,

$\mathrm{U}$ is the mean wind speed at ground level, and

$\mathrm{M}$ is the moisture content of the soil.

The average ground level wind speed and soil moisture content were assigned values of $2.5 \mathrm{~meters} / \mathrm{sec}$ (Hunter, 1997) and 0.25 percent (Looney, 1990), respectively. The multiplier $\mathrm{k}$ is given values of $1,0.35$, and 0.11 for total particulate matter (TPM), PM10, and PM-2.5 (particulate matter less than 2.5 microns), respectively. The emissions estimates summarized in Table 3 (excavation) were based on 85,000 cubic yards $\left(\mathrm{yd}^{3}\right)$ of soil excavated, transported, and dumped in an adjacent disposal area ( 2 transfers) and an additional $40,000 \mathrm{yd}^{3}$ excavated and used for backfill (1 transfer). Hourly emission rates were based on the assumption that total emissions calculated from equation 1 occurred uniformly over 120 ten-hour days (Sessions, 1999).

2. Emission factors for grading operations, in pounds of particulates per vehicle mile, are defined by EPA (1998a) as:

$$
\begin{aligned}
& \mathrm{E}(\mathrm{TPM})=0.04(\mathrm{~S})^{2.5} \\
& \mathrm{E}(\mathrm{PM}-10)=0.031(\mathrm{~S})^{2} \\
& \mathrm{E}(\mathrm{PM}-2.5)=0.0012(\mathrm{~S})^{2.5}
\end{aligned}
$$

Average vehicle speed, $\mathrm{S}$, was assumed to be 5 miles per hour. Total emissions from grading were based on a single grader operating 10 hours per day for 120 days.

3. Fugitive emissions from the movement of heavy vehicles over unpaved roads (in kilograms of dust per vehicle kilometer) is given by (EPA, 1998b) as:

$$
\mathrm{E}=\mathrm{k}(\mathrm{s} / 12)^{0.8}(\mathrm{~W} / 3)^{0.5} /(\mathrm{M} / 0.2)^{0.4}
$$

where

$s$ is the silt content of the soil,

$\mathrm{W}$ is the mean vehicle weight,

and $\mathrm{M}$ is the moisture content of the soil.

The average silt content of SRS soils is about 15 percent (Looney, 1990). 
Emissions estimates were calculated using a fleet average weight of each category of vehicle identified in the equipment inventory (Sessions, 1999). The vehicle fleet was assumed to travel an average of $80 \mathrm{~km} /$ day on the construction site during the site preparation phase (primarily dump trucks) and between $10 \mathrm{~km} /$ day and $16 \mathrm{~km} /$ day during the facility construction.

Batch plant emissions were calculated using an emission factor of 0.06 pound TPM per cubic yard of concrete produced (EPA, 1986). Batch plant emissions in Table 3 are based on a plant with a capacity of $150 \mathrm{yd}^{3}$ per hour (Pair, 1999).

\section{Dispersion Model Configuration}

Release 3 of the Environmental Protection Agency's Industrial Source Complex - Short Term (ISCST3) model (EPA, 1995) was used to perform calculations for:

- All operational emissions including process building stacks and diesel generators,

- Emissions from the exhaust of diesel-powered construction equipment, and

- Emissions from the concrete batch plant supporting construction

Model input parameters were set to invoke a 'regulatory default' option which utilizes generic values for the vertical profile of wind speed and potential temperature gradient and invokes algorithms to simulate stack wake downwash and enhanced mixing from turbulence generated by buoyant plumes, as applicable. In addition, the model was set to accommodate variable elevations for sources and receptors.

The receptor network used for all site boundary calculations consisted of a set of 180 grid points placed along the SRS perimeter. The receptor spacing ranged between $30 \mathrm{~m}$ and 1 $\mathrm{km}$ depending on the configuration of the boundary and proximity to significant sources of air pollution. Receptor elevations were taken from U. S. Geological Survey 1:48000 scale maps. This receptor configuration is used for most regulatory modeling applications at SRS.

A polar grid configuration was used to calculate impacts to the hypothetical co-located worker. A total of 90 grid points were placed in 4 degree increments at the prescribed radial distance of 640 meters. In addition, the receptors were placed at an elevation of 1.8 meters above ground to simulate the breathing height of a typical adult.

The concentration averaging time for each calculation was set to the value specified by the SCDHEC or OSHA standards (see Tables 4 and 5, respectively). The OSHA standards are expressed either as an 8-hour time weighted average (TWA) or as a ceiling value. The ceiling values were determined by calculating a 1 hour average with ISCST3 (the minimum averaging period allowed by the model), then manually adjusting the one hour value to a 15-minute average using the following algorithm:

$$
\mathrm{C}_{15 \min }=\mathrm{C}_{60 \mathrm{~min}}(60 / 15)^{0.2}(\mathrm{EPA}, 1988)
$$

where $\mathrm{C}$ is the ground-level concentration and averaging time is indicated by the subscript. 
Meteorological data used in the calculations consisted of sequential hourly averages of wind speed, wind direction, turbulence intensity (stability), and temperature from the onsite meteorological tower network and concurrent hourly values of mixing height (rural) derived from twice-daily upper air data from Atlanta, GA. The onsite meteorological data are collected at a height of 200 -feet above ground. A one-year data set for 1996 was used.

The EPA's Fugitive Dust Model (FDM) (EPA, 1992) was used to model 'fugitive' emissions of particulates from batch transfers of excavated soils and stirring produced by the movement of trucks, graders, and other heavy construction vehicles. The FDM is commonly used for this application because it can easily accommodate 'area' sources and because it uses superior algorithms for calculating deposition. Five particle size classes were defined for emissions of total particulates (greater the $500 \mu, 100-500 \mu, 10-100 \mu, 1$ $10 \mu$, and less than $1 \mu$ ); three size classes were used for PM-10 emissions (5-10 $1-5 \mu$, and less than $1 \mu$ ). The fraction of particulates assigned to each particle size class was derived from an analysis of SRS soil conducted by Looney (1990). Model default values for deposition velocity and gravitational settling by particle size class were used. Roughness length and average particle density were assigned values of $20 \mathrm{~cm}$ and 2 grams $/ \mathrm{cm}^{3}$, respectively. The receptor arrays and the meteorological data set used for the FDM calculations were identical to those used for ISCST3.

\section{Results}

\section{Impacts with Respect to SCDHEC Standards}

Estimated site boundary concentration maxima for postulated emissions from SD operations are summarized in Table 4 (Standard 2 pollutants) and Table 5 (Standard 8 pollutants). These tables also summarize the most recent SRS 'baseline' concentration established for each of these pollutants. The baseline values consist of the sum of a calculated maximum site boundary concentration, based on maximum potential emissions from all sources of the pollutant at SRS (Hunter, 1998), and the maximum observed concentration of the pollutant (if available) at the nearest SCDHEC air monitoring station during 1997 (SCDHEC, 1998). The 'baseline' modeling included those sources that were not exempt from Clean Air Act Title V requirements. The SCDHEC Bureau of Air Quality uses the baseline values as a means of assessing the permitability of new or modified sources of air pollution at SRS.

For all alternatives, the incremental increase in the maximum site boundary concentration for each of the applicable Standard 2 pollutants is extremely small (less than one percent) with respect to the existing SRS baseline and does not result in a cumulative concentration that exceeds any of the ambient standards. (Note that Table 4 provides ambient concentrations of total volatile (reactive) organic compounds as a conservative bound on incremental increases in ozone concentration. Explicit modeling of ozone is not a regulatory requirement at this time). The maximum site boundary concentration of total VOC is higher for the STP alternative than for the other alternatives due to higher emissions of benzene. 
WSRC-TR-99-00403 (Rev. 1) (SRT-NTS-00141)
Non-Radiological Air Quality Modeling for the Salt Disposition Environmental Impact Statement

Incremental increases in estimated maximum concentration of the Standard 8 pollutants are somewhat greater relative to 'baseline' concentrations than those observed for the Standard 2 pollutants; however, cumulative concentrations are also very small relative to the ambient standards. The baseline concentration listed in Table 5 for benzene includes sources that will be supplanted by SD implementation.

Table 6 summarizes the estimated cumulative increase in ambient pollution concentrations at the site boundary from implementation of the preferred SD alternative (STP) and the preferred alternatives for six additional activities planned for implementation at SRS (Disposition of Highly Enriched Uranium, Interim Management of Nuclear Materials, Tritium Extraction, Management of Plutonium Residues and Scrub Metal Alloy, Spent Nuclear Fuel, and High Level Waste Tank Closure). Again, the cumulative increase in air pollution emissions is not expected to adversely impact the ambient standards.

\section{Impacts with Respect to the OSHA Standards}

Concentration maxima for the hypothetical co-located worker are summarized in Table 7. Estimated concentrations for this receptor are negligible with respect to the applicable standards except for $\mathrm{NO}_{2}$, which is approximately 90 percent of standard. The $\mathrm{NO}_{2}$ emissions for all SD alternatives result from periodic operation of the diesel generators. Since concurrent operation of the diesels is highly unlikely, the estimated $\mathrm{NO}_{2}$ concentration given in Table 7 should be considered quite conservative.

\section{Impacts Related to SD Construction}

Estimated concentration maxima from construction-related emissions are summarized in Table 8 (Standard 2 pollutants) and Table 9 (OSHA pollutants). Concentration maxima for each averaging time were computed for each of the two phases of construction. The values summarized in the tables are the higher of the two sets of calculations. Construction-related impacts are negligible with respect to both the SCDHEC and OSHA standards, except for $\mathrm{NO}_{2}$ emissions which result in a concentration maximum that is approximately one-half the standard. 


\section{References}

Hunter, C. H., Air Dispersion Modeling for the SRS Title IV Air Permit Submittal, SRT-NTS-980019, Rev. 1, (1998).

Hunter, C. H., Meteorological Annual Report for 1996, WSRC-TR-97-0214 (1997).

Gladden, J. B. , Site Selection for the Salt Disposition Facility at the Savannah River Site, WSRCRP-99-00513, Rev. A (1999).

Looney, B. B., et al, Geochemical and Physical Properties of Soils and Shallow Sediments at the Savannah River Site, WSRC-RP-90-1031 (1990).

Pair, C. Concrete Batch Plant, inter-office electronic communication to C.H. Hunter (1999).

Pike, J. A., Preliminary Source Term and Emissions Data for Salt Processing Environmental Impact Statement, WSRC Inter-office Memorandum HLW-SDT-99-0161, Rev. 4 (2000).

Sessions, J. R., SRTC Non-Rad Air Emissions Data Needs for Construction Activities (DOE/EIS0082-S2), WSRC Inter-office Memorandum HLW-SDT-99-0151 (1999).

South Carolina Department of Health and Environmental Control, South Carolina Air Quality Annual Report, Volume XVII 1997 (1998).

U. S. Department of Energy, Defense Waste Processing Facility Salt Disposition Technology Options at the Savannah River Site, Supplemental Analysis, DOE/EIS-0082-SA-03 (1998).

U. S. Environmental Protection Agency, User's Guide for the Industrial Source Complex (ISC3) Dispersion Models, EPA-454/B-95-003b (1995).

U. S. EPA, A Workbook of Screening Techniques for Assessing the Impacts of Toxic Air Pollutants, EPA-450/4-88-009 (1988).

U. S. EPA, User's Guide for the Fugitive Dust Model - Volume 1, EPA-910/9-88-202R (1992).

U. S. EPA, Nonroad Engine and Vehicle Emissions Study (NEVES), Report 21A-2001 (1991)

U. S. EPA, Compilation of Air Pollutant Emission Factors, Fifth Edition, Vol. I: Stationary Point and Area Sources - Section 13.2.4, Aggregate Handling and Storage Piles, AP-42 (1995).

U. S. EPA, Compilation of Air Pollutant Emission Factors, Fifth Edition, Vol. I: Stationary Point and Area Sources - Section 11.9, Western Surface Coal Mining, AP-42 (1998a).

U. S. EPA, Compilation of Air Pollutant Emission Factors, Fifth Edition, Vol. I: Stationary Point and Area Sources - Section 13.2.2, Unpaved Roads, AP-42 (1998b).

U. S. EPA, Compilation of Air Pollutant Emission Factors, Fifth Edition, Vol. I: Stationary Point and Area Sources - Section 8.10, Concrete Batching, AP-42 (1986). 


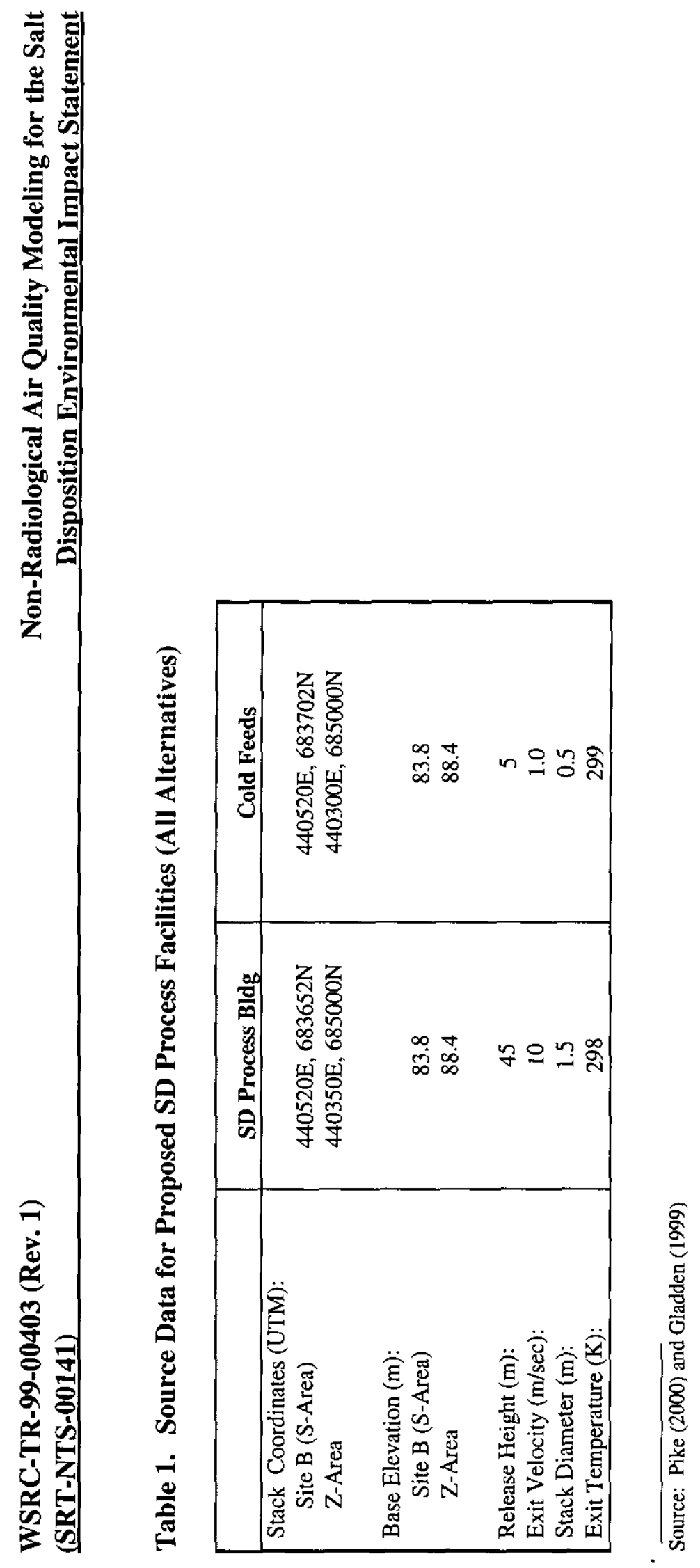




\begin{tabular}{|c|c|c|c|c|c|}
\hline \multicolumn{3}{|c|}{ 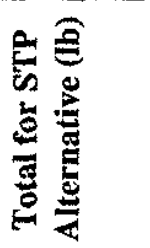 } & \multicolumn{3}{|c|}{ 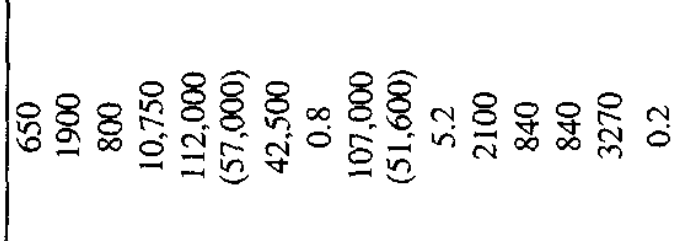 } \\
\hline \multirow{2}{*}{$\frac{\mathfrak{Z}}{4}$} & & 竎 & 용요 유윯 & 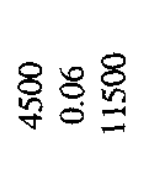 & ก: \\
\hline & & 氕 & $\widetilde{\sigma}+\stackrel{\infty}{\sim} \stackrel{\infty}{\circ} \underset{\sim}{\sigma}$ & 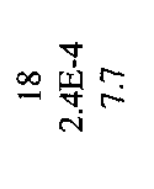 & 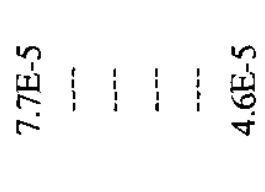 \\
\hline \multirow{6}{*}{ 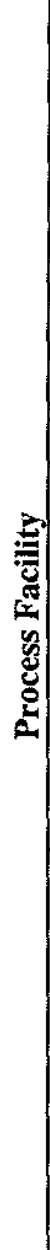 } & 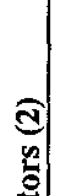 & 金 & 용 8 & $\underset{\substack{\infty \\
\infty}}{\oint_{0}}=$ & 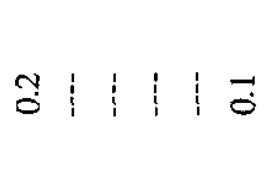 \\
\hline & 窇 & 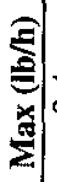 & ث্ণ & 号岱势 & 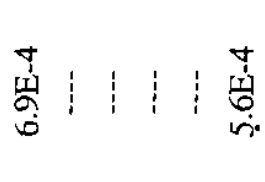 \\
\hline & \multirow{2}{*}{ : } & 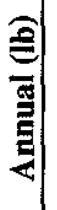 & $1: 8$ & ! & 曽导导용 \\
\hline & & | & $1: \stackrel{0}{0}$ & 守 & 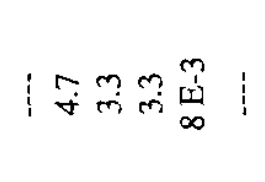 \\
\hline & \multirow{2}{*}{ 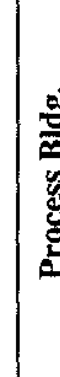 } & 을 & 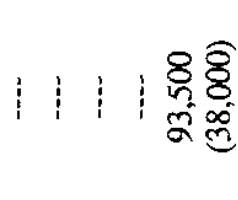 & 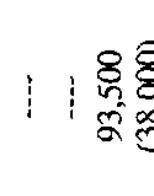 & 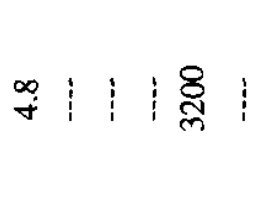 \\
\hline & & సิ & $1 \quad 10$ & ! : & 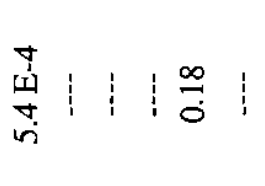 \\
\hline & & & ×气 & 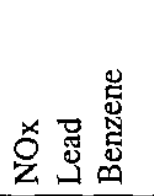 & 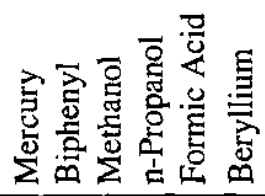 \\
\hline
\end{tabular}

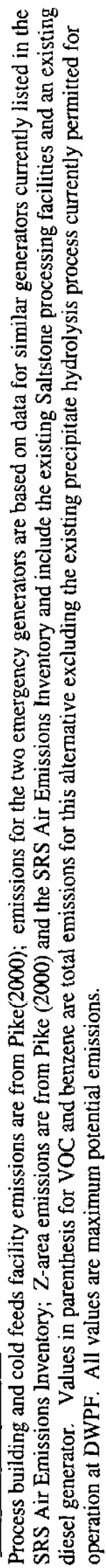



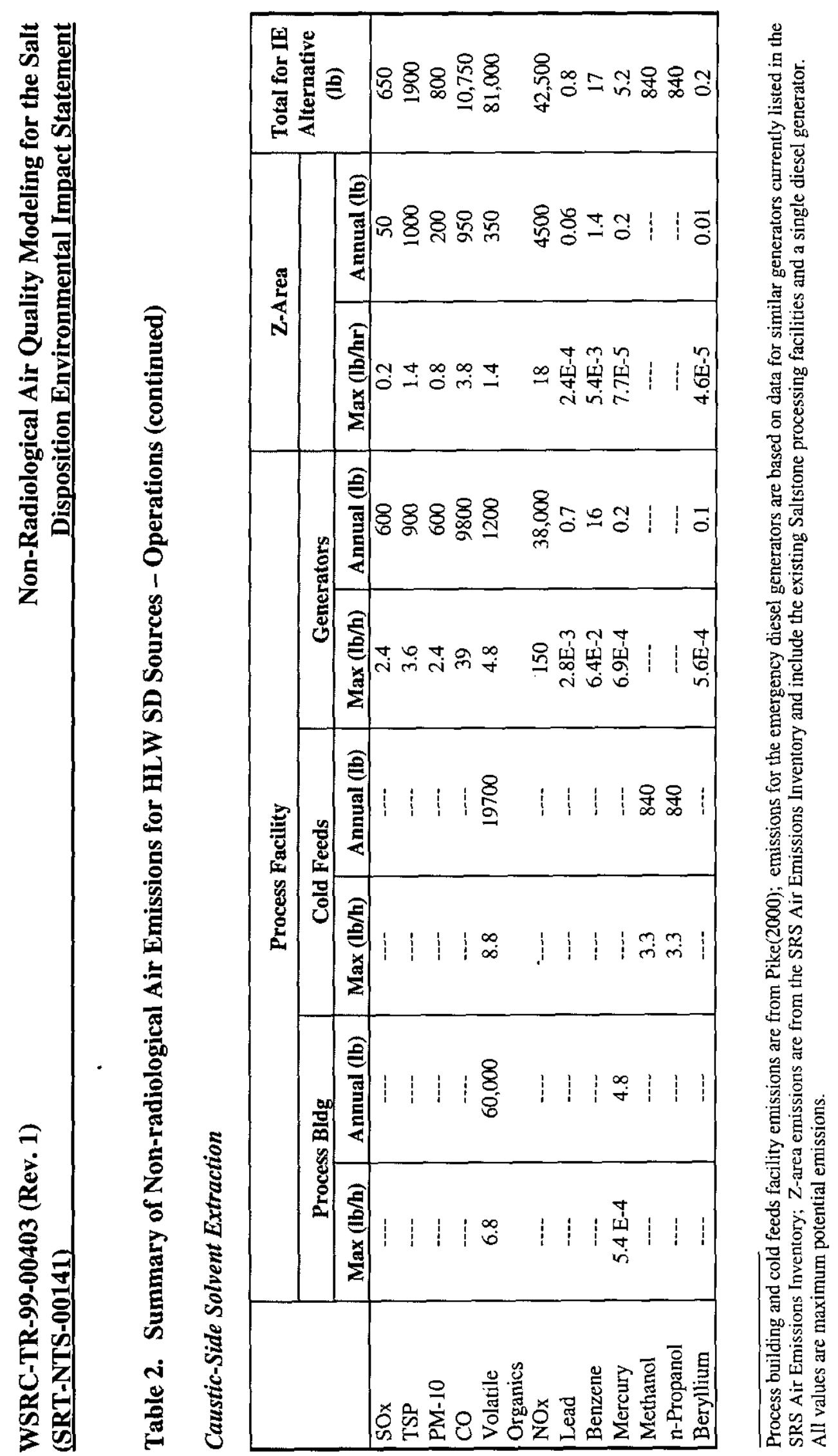


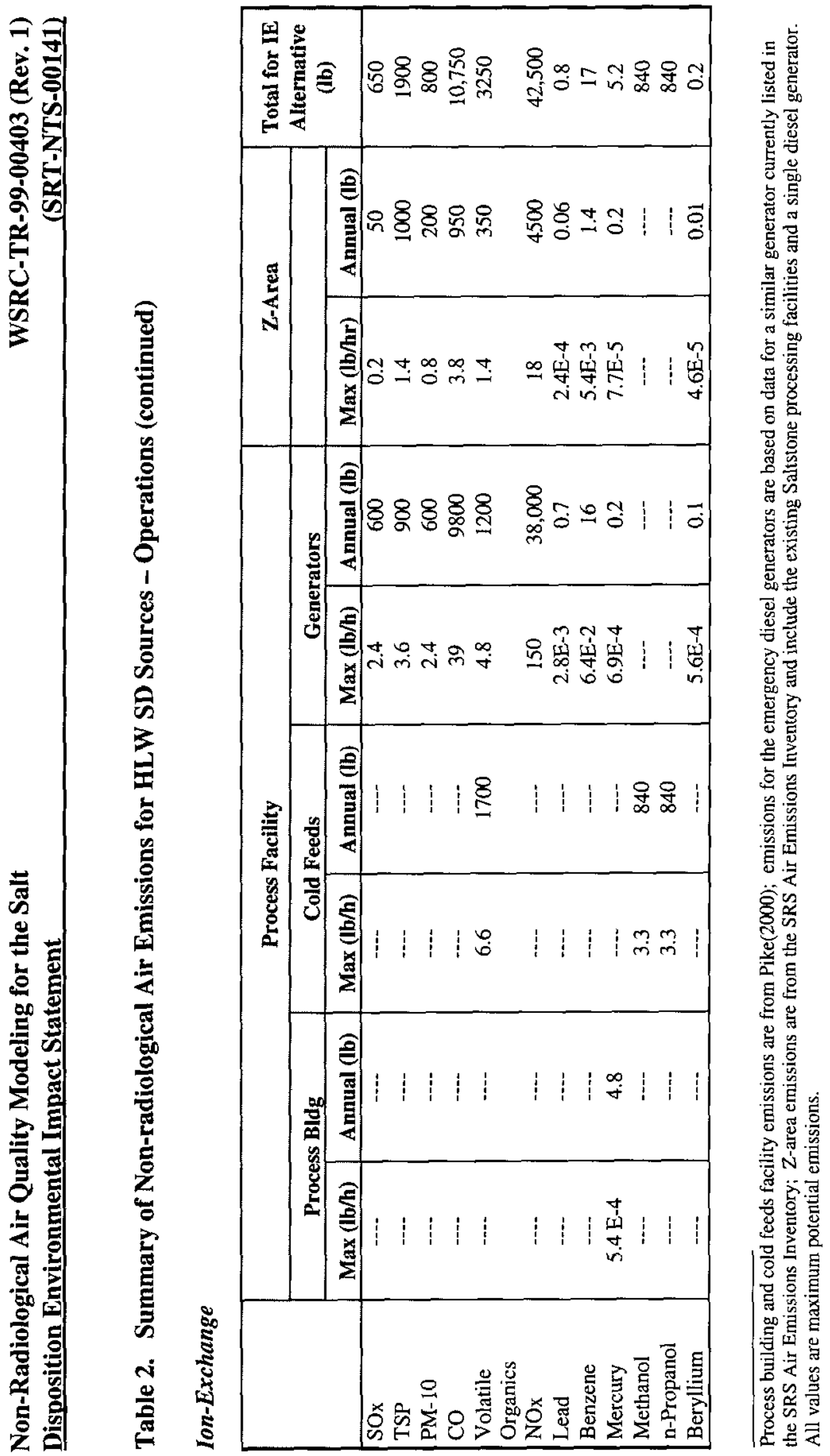




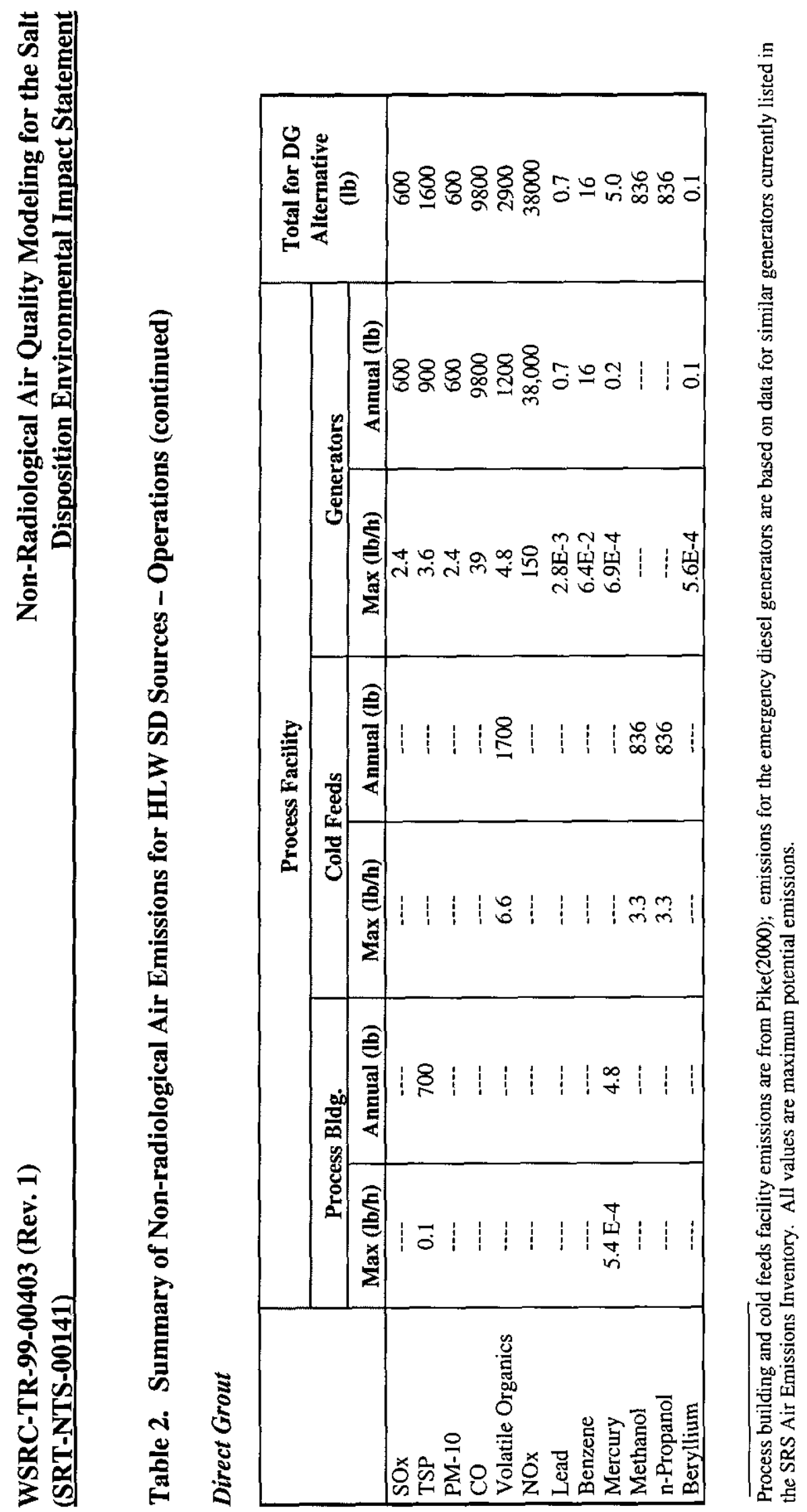



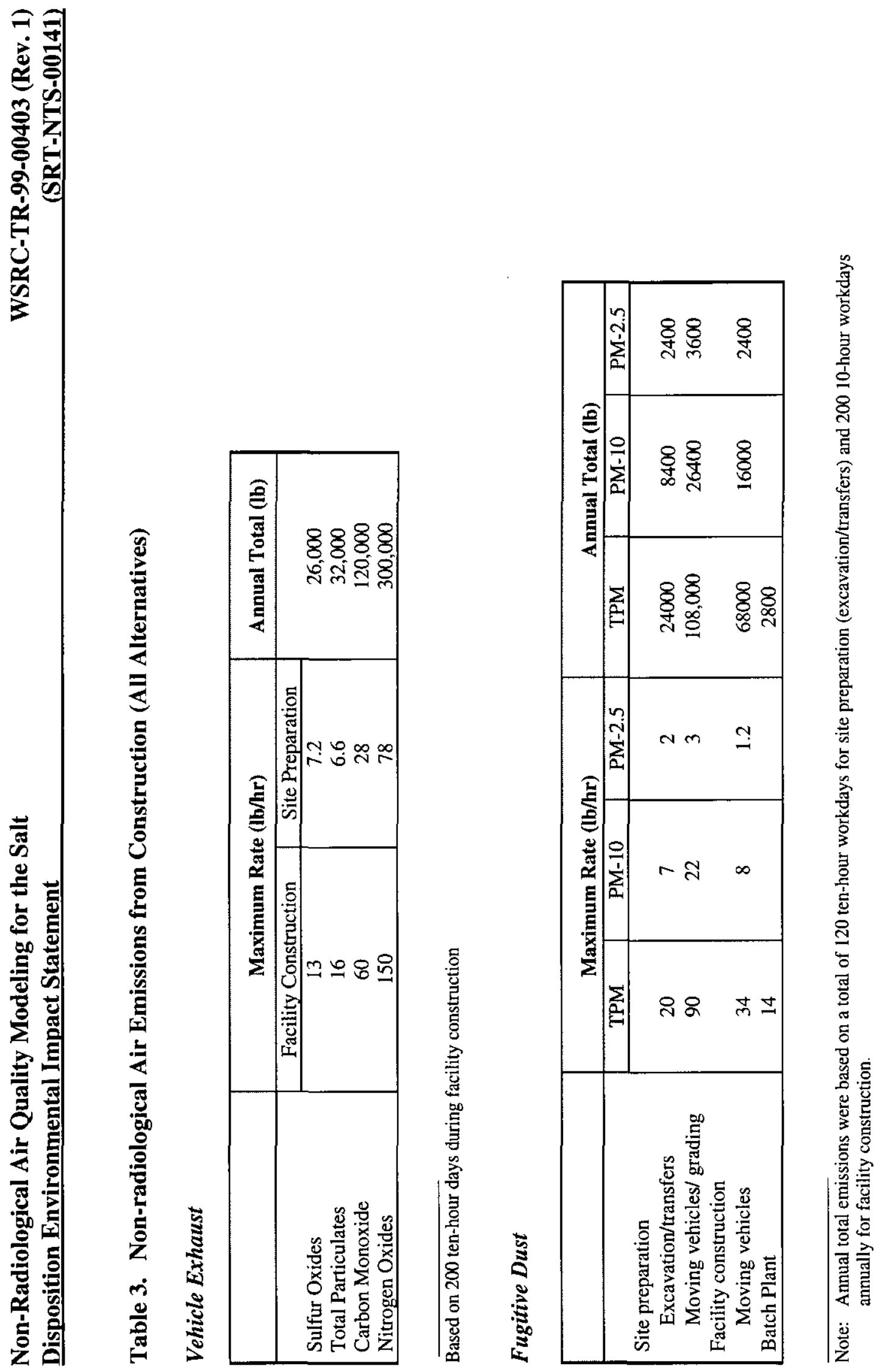


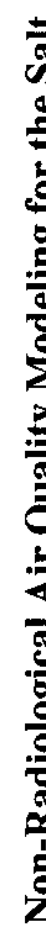

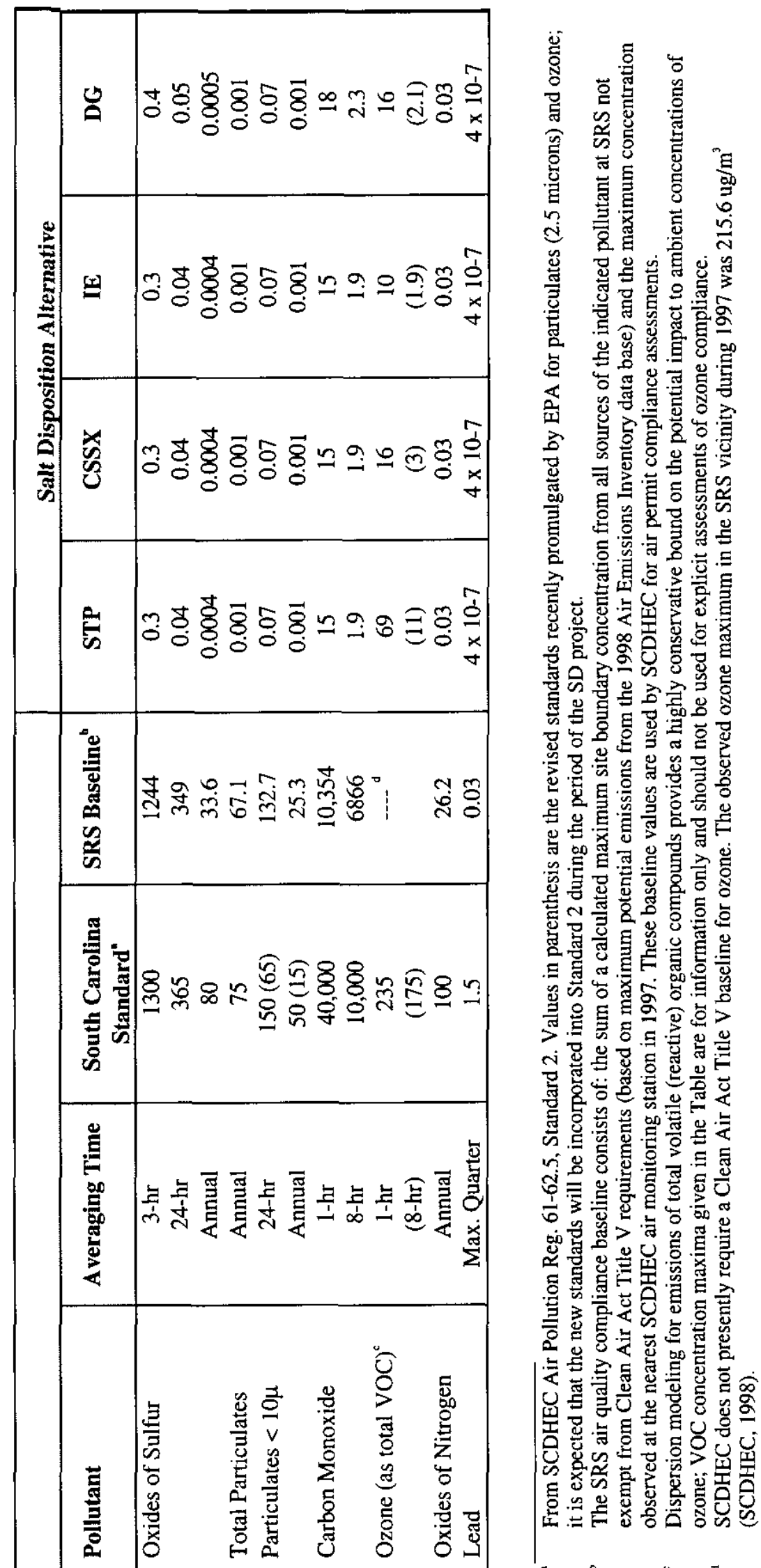




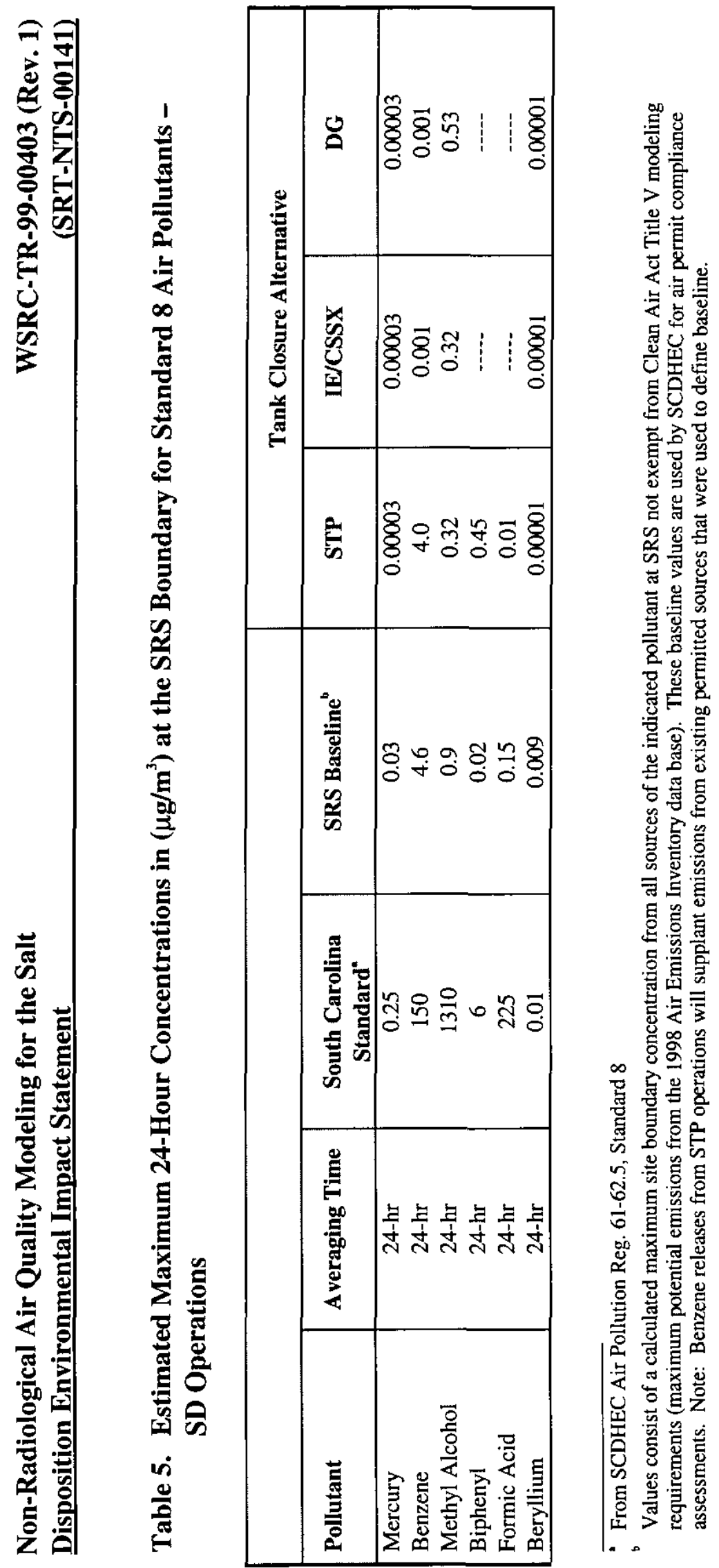




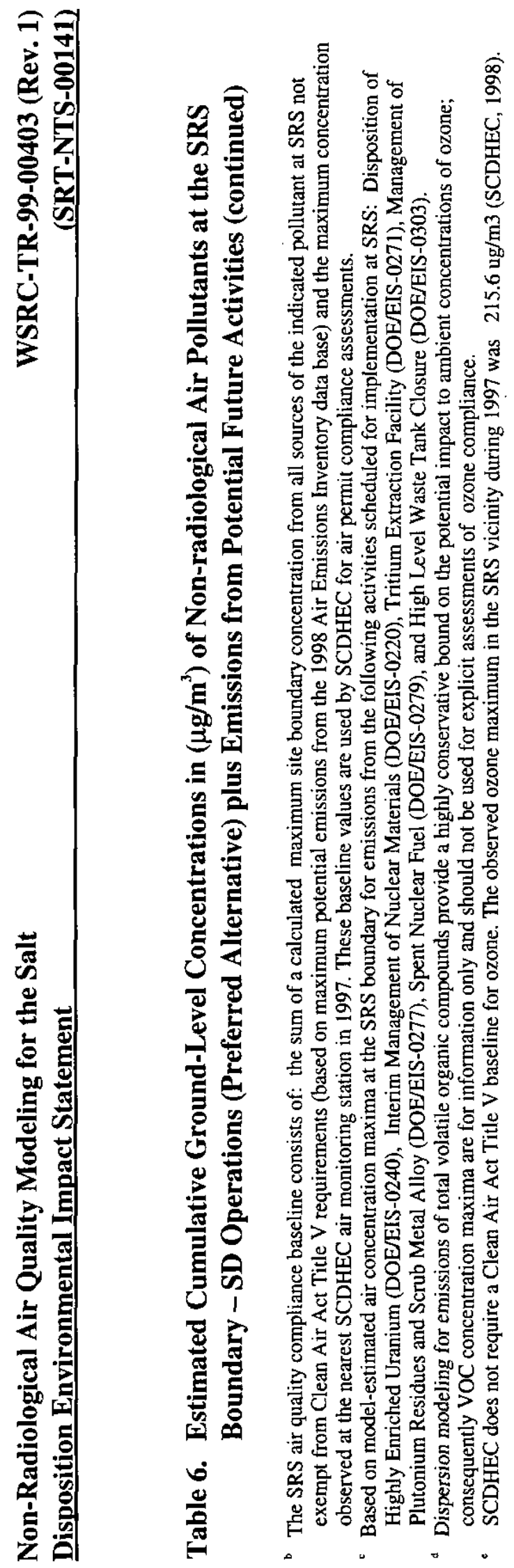

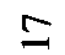




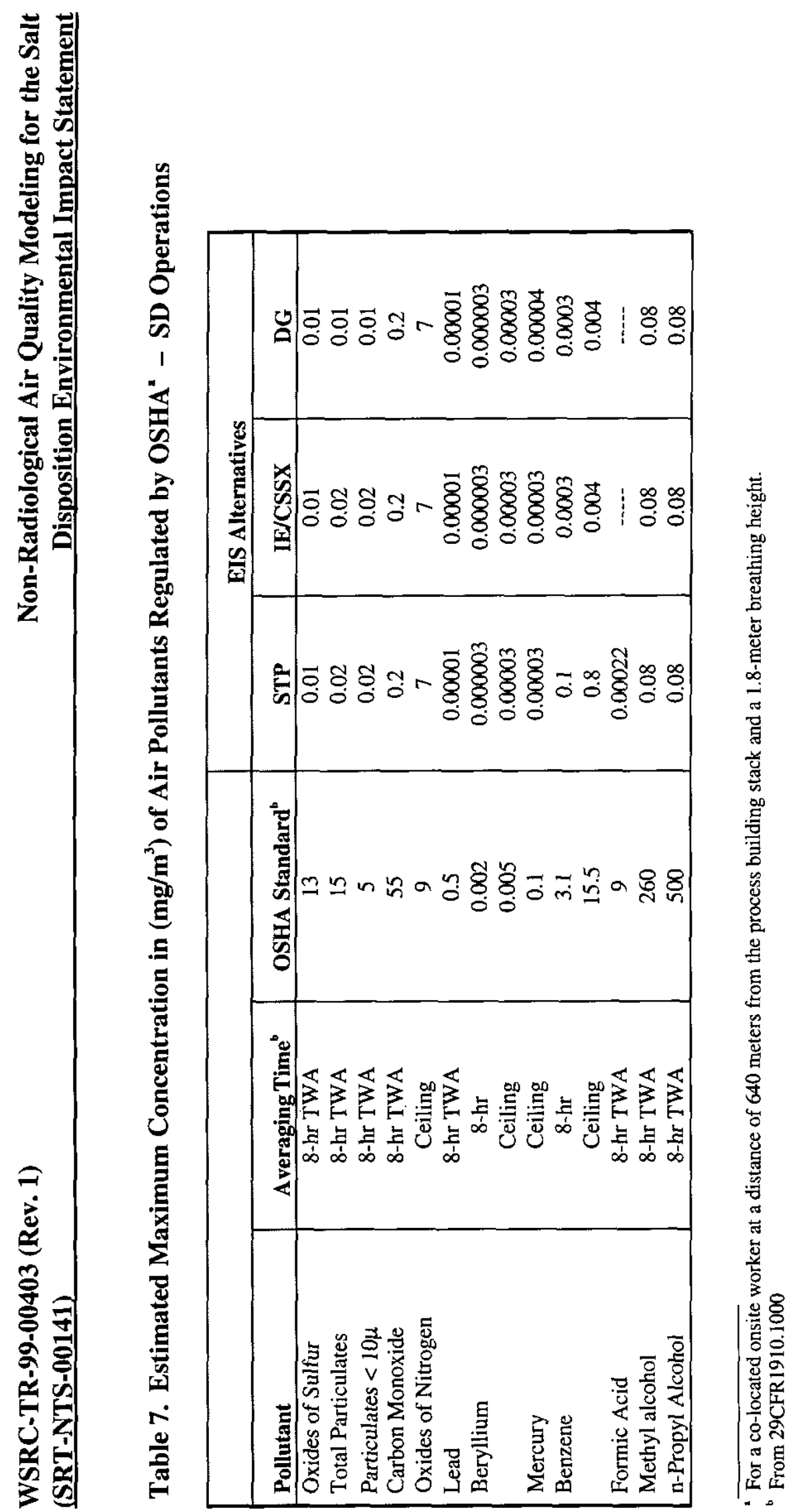




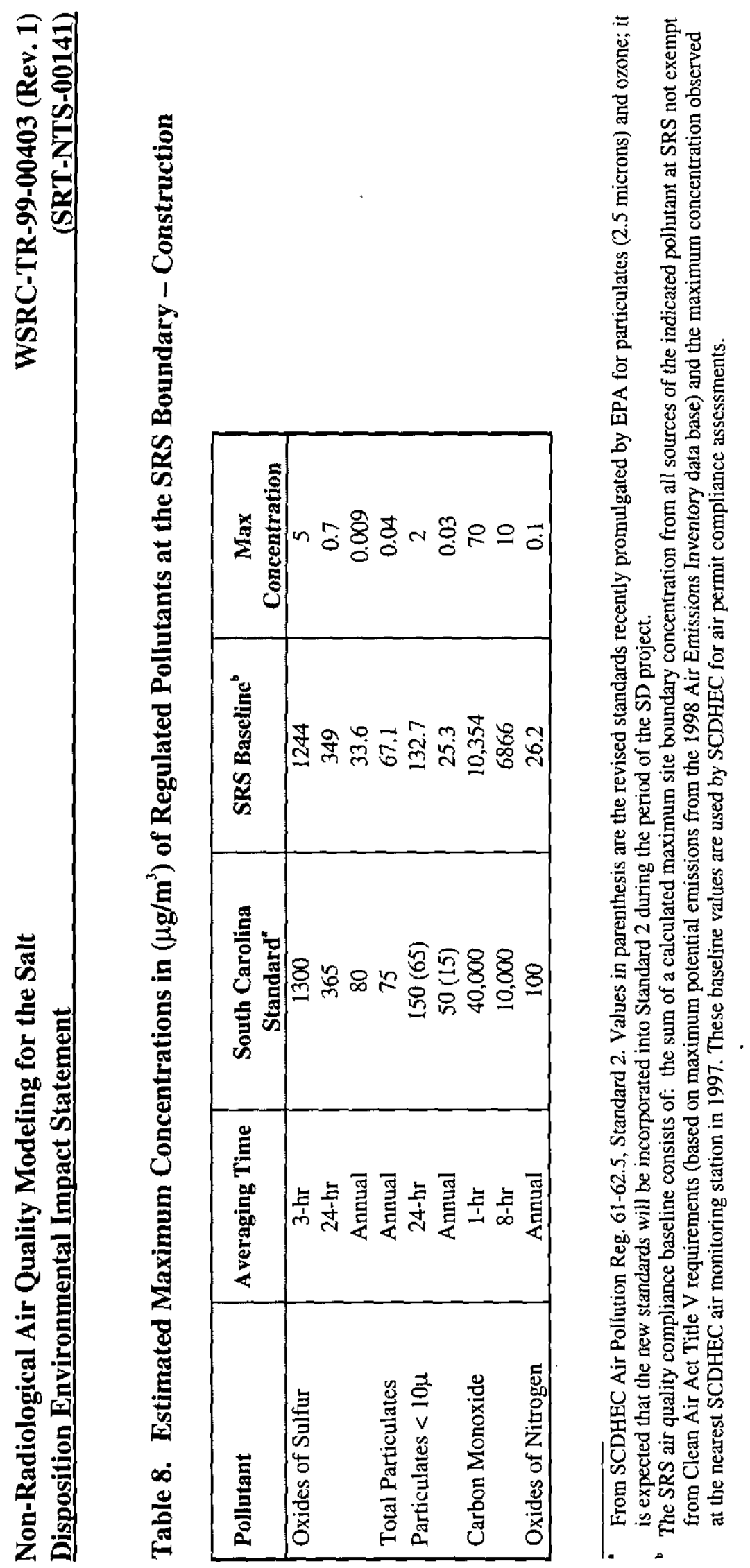

2 


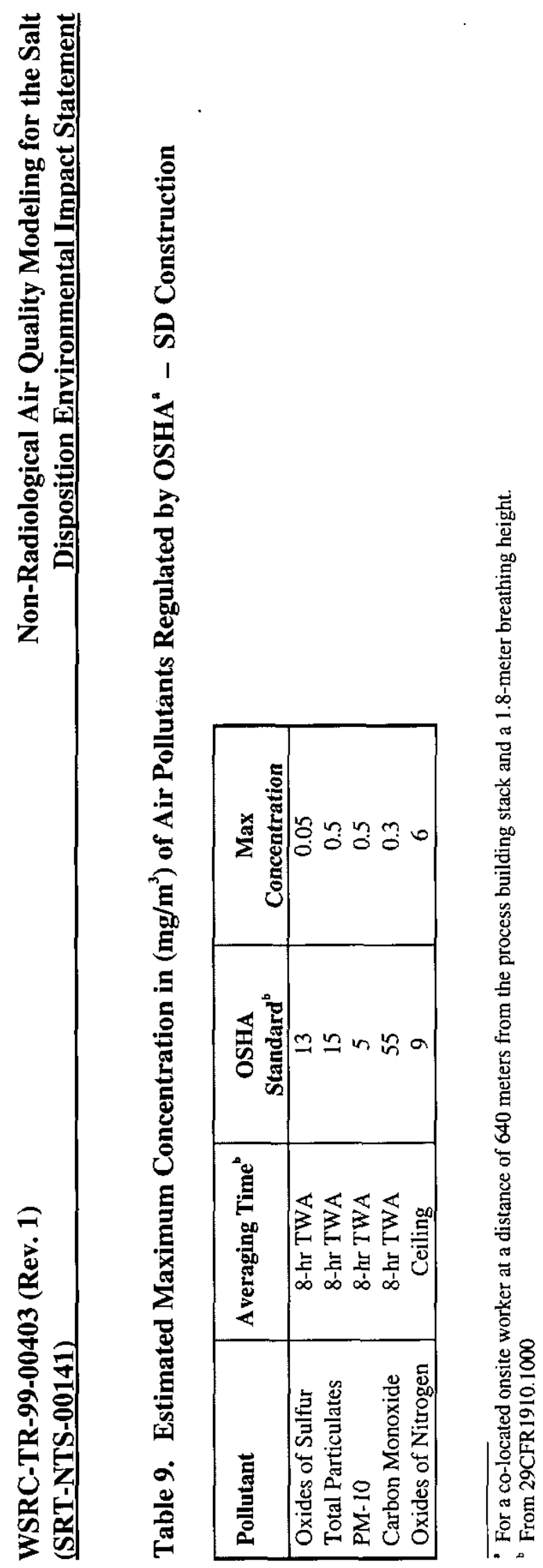

